\title{
Rules Governing the Occupation of Nationalized Territory Subject to National Law of the Jungle
}

\author{
Nasrollah Amin Kaleibar \\ Lawyer of Justice, Academic member of Kaleibar Branch, PNU, Iran
}

\section{Doi:10.5901/mjss.2016.v7n3s3p36}

\begin{abstract}
All forests, meadows, natural woods and Woodlands are part of public property belonging to the state to protect and restore and develop these resources and exploitation of the forest is on the Bonnie Iran (1). (See Article 2 of the Law on the protection and exploitation of forests, adopted in 1346). In fact, it notices that these national lands unauthorized occupation by natural or legal persons - Both public and private - these organization for legal obligations mentioned in the complaint against them. In relation to possible criminal prosecution by the proprietor of the national territory, before the closing of the aforementioned organization, different approaches have been proposed. In this paper an attempt is also blind religious views, the relevant legal provisions, the legal department comments judiciary one of the above to assay and analysis.
\end{abstract}

Keywords: National territory, Disseise, National protest of the Earth.

\section{Introduction}

By virtue of a national law adopted by the nation's forests 10/27/1341: "field and the peerage of all natural forests and pastures and woods and land battle of the property (2) And is owned by the government. Even though it occupied before the date of the document are the property taken."

Natural forest or grassland or forest or grassland or forest thicket of words is not created by the parties. (Paragraph A of the Implementing Regulations, the national law of the jungle) The three categories of forest are satisfied.

- They are evidence of forest land and forest trees such as seedlings or sprouts provided that there is a group or scattered on the nationalization of forests and cultivated crops not or ash is an annual.

- Trees are sparse forest land vehicles exist and size of the trees to the north from Astra to Glydaghy less than one hundred cubic meters per hectare and in other areas of less than twenty cubic meters.

- How to plant a tree or forest lands that are dense or sparse and they exist in. (Paragraph 5 above article)

Ranging from wooded grassland and wooded.

- Non-wooded pasture land, including mountain slopes or flat ground cover in the season because of forage plants and vehicles with regard to the history of grassland known as grassland.

- Wooded grassland pasture that has trees and get the volume of trees per hectare over one hundred cubic meters (Paragraphs 6, 7 and 8 above article).

With the Islamic Revolution and the constitution and the adoption of Sharia legal and public forests were among the public wealth. Article 45 of the constitution are the lyrics to "public wealth assets such as land your hair or abandoned, forests, marshlands, natural woods, meadows, which is optional, and so the Islamic government to act in accordance with the public interest to them. "

The national government's action in the meadows, forests, forest lands and natural woods, and is considered one of the rule of private property on public land could be the due to decline. In the other words, in accordance with Article 22 of the Registration Act, departments and State courts are the only one who recognizes it as the owner of the property is registered in his name in the real estate office but the sentence is contrary to the government to recognize the forest or rangeland the exception of... . The above principle, public ownership and private ownership of the land is made of the type of property - because of the general population - ended.

Considering the importance of and the need for strict enforcement of the provisions of national forests, national lands and handling procedures initially objected to the decision will be explained. 


\section{First Speech: National Land and handling procedures to protest against the nationalization of land}

If what national law in accordance with Article One of forests, fields and forests all the peerage as public property is owned by the state, so long as the property of the void in accordance with the criteria set forth in the law and other laws, including the protection and exploitation of forests and compliance with the procedures stipulated in the regulations related to natural resources such as forests, grasslands, and.... is detected, it cannot be considered to be national. In other words, the effect provisions in national law of the jungle, unlike the appearance of a text phrase and its reason material that, pending the determination of the detection and diagnosis of meadows and forest and offices above the effects of phonological facility. (Shamsol, 1385, pp. 65)

Recognition of national resources and the excluded (3) the national law of the jungle and often in compliance with the definitions set forth in the conservation and utilization of forests with the Ministry of Natural Resources - Current Ministry of agriculture - . (See Article 56 of the Law on the protection and exploitation of forests) in recognition of the land as forest, grassland or forest lands must comply with the legal formalities.

\section{First Paragraph: The National Land and procedures}

In recognition of the national territory subject to national law of the jungle, the rules implementing Article 56 of the Act of 28/04/54 protection and exploitation of forests and protect the implementing regulations of Article 2 of natural resources and reserves of the forest Act of 16/12/71 is necessary.

\subsection{Visit, reporting and issuing assessment}

Ministry of agriculture - of forest, Rangeland and Watershed Management - when the detection zone to deploy the agent. Agent visitor map area should visit the area and if not possible, to sketch the necessary research to develop and appropriate means to visit the area and legal execution do, thereby obtaining a building if, after the adoption of national legislation on the construction of the building and its reasons in writing and leaves visitors with a comment, the one who commissioned the investigation, submit. (article 3 of regulation implementation of article 52 of the law).

Visitors must leave the unit after receiving the report and ensure the accuracy of its contents in accordance with the provisions of article 56, an attempt to detect issuing. (Ritual this letter article 4) Leaves characterize the situation as a national resource of natural and legal definition of the profile records, layout agro, location, extent and area visited and exceptions to article 2 of the National Forest, with inquiries from the authorities cited and when viewed in the border area, mountain or river or highway or public road, there is described a convenient location and its exceptions to any specific terms. (Article 2 of the rules of procedure)

\subsection{Publishing notice}

After issuing a public notice of the action to detect and diagnose these provisions leaves published. The notice referred to in Article 56 of the law of conservation and utilization of forests and Article 2 of the Law of natural resources and protect the forest reserves In addition to the mass-circulation newspapers and local newspapers, to separate Tex Meyer and Moran by police officers to inform people on the streets and public places is attached. The notice must be taken of the objections and in the absence of the protest. Police officers Law required within one week's notice in writing to the reference attached and shall declare the ad. (Note 3 above article)

\section{Section II: How to deal with objections to the national recognition of the Earth}

Recognize Land or land belonging to natural or legal persons, as the case may be evidence of forests, forest lands, rangelands, forests and meadows of the national law of the land or land diagnosis and deterioration of private property, always interested parties are protesting.

\subsection{Interested parties}

Article 56 of the Law on the protection and exploitation of forests and rangelands, stated: "Interested parties can view the ministry (Ministry of Natural Resources) Protest ... "Wrote a definition of interested parties did not matter to determine whether the law of the land dispute with the implementation of Article 56 of the law of conservation and utilization of 
forests and regulations of the relevant issues relevant persons Benefit was determined.

\subsection{Land owner farmers Layout}

Land owner farmers Layout refers to people who, according to the rules and regulations of agrarian reform, agricultural Layout been entrusted to them or in statistics of the farmers who cultivated layout be. (Section A of the Executive Law amended Regulations duty land dispute issue implementing Article 56) Given that the national law of the land covered by forests and cultivated land as uncultivated land on it own have been excluded from the outside and above the law and therefore persons working in the implementation of regulations land reforms, to agricultural land, Gardens granted to them, they can identify the forest And Rangeland and Watershed country's national (uncultivated on it own) of land under protest and driving violation and revocation decisions shall be demanded.

\subsection{Owners}

Whether legal or natural persons referred to agricultural lands and buildings Yagh the title or certificate of ownership or representative office agrees definitive rulings issued by the court, ownership of the date of approval of forest The country is realized. (Paragraph 2 above, however, the vote of the General Board of Administrative Justice Court No.79/99, has been canceled.) Persons mentioned in Article 3, Article 2 of the Law on National Forests are the lyrics to "the land approved equipment and rural homes and land and gardens in the event of ownership documents, which are subject to the ratification of the construction of It was not a matter of law, be it national (the uncultivated on it own diagnosed) of land or land detection, object."

\subsection{The owners of gardens and plants}

The entities referred to in the documents referred to in paragraph 2, claiming ownership of the domain are land gardens and facilities. (Paragraph 3 of Article I of the amended by-law of the land disputes in the implementation of article 56 of law rule)

These three entities can provide positive evidence of their right to national territories, and their protests on the ground or grounds of national diagnosed diagnostics, announced. It is noted that in addition to the aforementioned individuals, organizations and believers governmental institutions to implement article 56 of the Law on the Protection and Utilization of Forest and Rangelands and its subsequent amendments have appealed to the Board based its objection which can be expressed in a single article of the law determine the implementation of article 56 of the land dispute the protection and exploitation of forests.

\subsubsection{The deadline for objections}

In the former, they are not interested parties to you within one month after the written notice or notice by the Ministry of Natural Resources, one of the centers of mass circulation newspapers and one local newspaper and other usual and proper location of the Ministry and the protests ads must submit their reference issuer. (Article 56 of the law of conservation and utilization of forests)

With the approval of the final implementation of Article 56 of the law of conservation land dispute exploitation of forests adopted on 22/06/67, the deadline for interested parties to protest the implementation of Article 56 has been deleted and are without observance of the time limit, the implementation of Article 56 to identify areas of challenge.

\subsubsection{Reference to handle objections}

Law to determine differences in the implementation of Article 56 of the law of land conservation and utilization of forests explosion "self-interested parties can appeal to a delegation consisting of the office of farmers, officials Forestry run, Jihad members, properties, land tenure, one judge and two members of the village council or the local tribes that formed in each city under the Ministry of Construction. The Council of the Ministry of Jihad in every city and recognize the presence of at least 5 out of 7 people found the following opinion panel judge panel will be binding unless in cases under Articles 284 and 284 repeated three Sharia Law Criminal Procedure Act 6.6.61 '( Article 326 of the Civil Procedure Code)

Although the latter part of the single article mentioned above, only in the three judge panel under articles 284 and 284 of the Criminal Procedure Code, adopted on 06.06.1361ability protest was repeated, but with the implementation of 
the reform of rule land dispute 56 law on the protection and exploitation of forests on $05 / 03 / 87$, last section, the single article was amended thus: "The board or a judge, court of appeal, I think it is objectionable in the branches of. Obviously staff unofficial local experts can use as a bachelor."

Accordingly, the first time a month to protest the removal of national recognition and secondly stakeholders including landowners, farmers layout land owners, owners of gardens and public facilities and institutions to implement Article 56 of the law of conservation the operation of the forest will rangelands and its appeal to the Board of a single object can determine the territorial disputes in the implementation of Article 56 of the present. And thirdly, indecisive and staff judge in the court protest and appeal the site of a property, and unless the National recognition of the definitive reference on the Board considered that the decision of a single judge of the judgment of the Board raised the objection and appeal to protest against the verdict as the Appeals Court of First Instance and the to the does not know that the within the period for appeal to the court of first instance, appeal or not to appeal out of time to be diagnosed.

\section{Two words: national land tenure under the national law of the forest}

National Land Nationalization Act either forest or grassland, forests and forest lands, as the case may be owned by the stakeholders, including farmers layout land owners, and facility owners of gardens and corporations and government agencies by the parties and seized (4) And operation is unlicensed.

Forest, Rangeland and Watershed Management in accordance with Article 2 of the Law on the protection and exploitation of forests and other natural resources laws, including laws to protect the forests and reserves of the Act in order to protect and 12/07/71 natural resources of the national action plan against acting on the complaint duress.

The tenant complaints and criminal prosecution and punishment, according to the provisions of Article 56 of the Law on the protection and exploitation of forests and amendments are implemented is or not. Accordingly, in a separate paragraph for each of the above options.

\section{First paragraph: the uncertainty of the national land tenure}

When the Ministry of Agriculture - Department of Natural Resources ex - Nationalization of the land is deemed to be definitively held that the decision of the Board to determine a single article of land disputes in the implementation of Article 56 of the operation of the law of conservation forests and rangelands, to protest the results of the Board for as National recognition is being verified. The decision pursuant to a final judgment (5) Certainty is reached.

Article 55 of the Law on the protection and exploitation of forests is poetry. "Everyone has to capture the national resources in the forests of a country exceeds national law to a year to three years in prison will."

Seems to capture the subject matter, the purpose of acquiring and creating a national land tenure rights on their objective. It is important to capture the spiritual and material elements analyzed. The element consists of a series of events which took physical possession of the land makes such as physical exercise to keep, use and exploitation of the object or change by seizing on the spiritual elements that possess the property as the owner has. (Shams, 1385, p. 123)

The sanctions law enacted in 1361, after which the Penal Code Article 690 of the Penal Code duress of land was nationalized. Material provides: "Whoever by histrionics as you wake up, walls, change the interface, eliminating border, plot layout, piping streams, wells, planting trees and crops and the like, to obtain possession of the land is arable, whether cultivated or fallow crops, forests and national grasslands, mountains, gardens, nursery, water resources, the eyes of starlings, natural rivers and national parks, facilities for agricultural and livestock and agro-industry and barren and uncultivated land and property owned by the government or company and wasteland closed to state ... entitled to possession or attempted to introduce yourself to learn the punishment is imprisonment from one month to one year. "

According to the text of the duress of land and property owned by the state or private individuals to authorize punishment is prohibited. The criminal complaint in court if it can lead to the desired result plaintiff to prove that the belonging to After the plaintiff is required to prove their ownership in the case of property or right of possession or harassment prevention, evidence that the proof is necessary and other organs of the claims in criminal complaint should be as well regulations and standards adopted by the duress of civil litigation case assessment and judged. (Shams, 1382, p. 386)

According to Article 158 of the Civil Procedure Code "is to capture suit claims that the former proprietor of the immovable property of another without his consent, he removed him from seizing the property of their recovery requests».

The lawsuit claims the parties prove their right to property that may or may not be not hang Bo Dan forcible seizure of the defendant's claim, though here too read about the property, which may or property The handle is not available. (Shams, 1382, p. 355) 
By applying the provisions of Article 56 of the Law on the protection and exploitation of forests and subsequent regulations, former possessions and property of persons on public land and property lost and the seizure of individuals in the public interest representatives of the Ministry of Agriculture is established. Accordingly, on land formerly occupied public land, although the possessed, but adapted to the national law of the jungle, the possessions that he has no respect for the law and in accordance with Article 36 of the Civil Code "occupation that would prove to be caused by or not vector legal, valid, "the other side in history to win the general population and forcible seizure of possessions legal seized on state capture, captured the action for compliance with Article 690 of the Penal Code, does she deserve punishment Regulation will be.

\section{Section II: The national land tenure is uncertain}

In relation to possible criminal prosecution national land occupied by non-deterministic different views of legal scholars and policy space is also the return of Matt. Some are captured possible criminal prosecution and others full implementation of the provisions of Article 56 of the prosecution of the proprietor, not possible either. In this section describes each of these views is discussed.

\subsection{The possibility of criminal prosecution occupants}

Legal proceedings against the possibility of occupying public land are uncertain terms, that the adoption of a national law of forests, fields and forest lands and pastures aristocratic part of public property and ownership of the public property as is loppy. Deemed appropriate, that the rights of the individual rights of the preferred and corruption wherever it is required there have avoided it.

Because of the lack of prosecution of public land occupied by non-deterministic, causing widespread encroachment of public land by Joe profit is therefore deemed appropriate by the prosecution to avoid of them the occurrence corruption not be done.

However, under article 2 of the law of conservation and utilization of natural resources, national forests and grasslands maintenance is the responsibility of Forests and Rangelands and Watershed country - a former Forest Service - has been performing the task, requires that the national land tenure and duress of a complaint, the Court attempted to address and prosecute and punish the perpetrators.

Unlike the group, no objection to national recognition and acceptance of the land as an implied waiver of the objection of the land and who, despite knowing the aforementioned diagnosis and to protest against it. The plan is to continue the protest and refused to issue a final ruling at the same time attempting to capture the national territory, you have to remove their possessions, their action. Otherwise, the proprietor unjust, criminal prosecution.

Some courts ( Branch 1059 Tehran criminal court sentence of 198 - 07.17.86) by accepting the view of the above, the proprietor of the national territory by non-deterministic and prosecuted in accordance with article 690 of the Penal Code has been sentenced to imprisonment .

\subsection{Failing to prosecute captured}

According to this view assumes full implementation of the provisions of Article prosecute captured only in 56 of conservation and utilization of forests and pastures and subsequent amendments that may later may prove possible and on the evidence of his Citing have found.

First) according to Article 55 Law on the Protection and exploitation of forests, "the Ministry of Agriculture and Natural Resources shall be informed as soon as the danger by their forestry officers, repel the invasion. If the Ministry of Agriculture and Natural Resources at the deadline in the notice or advertisement is detected, in this case, stop and continue to be subject to criminal prosecution thus ensuring full implementation of the provisions of Article 56 shall be. "According to the note, the full implementation of the provisions of Article 56 proceedings proprietor only if it is possible.

B) Legal Office of the Judiciary opinion No. 97698 / 7-23 / 12/78 has been announced. "Before the definitive diagnosis of natural resources, aggressive prosecution, no justification, but the definitive diagnosis, the perpetrator should be prosecuted" (Golduzian, 1382, p. 411).

C) According to no. 35 dated 03.29.1353 in accordance with the vote of the General Assembly of the precedents of the Supreme Court, "according to Article 56 of the Act explicitly recognize the conservation and utilization of national resources Jungles Act of 1348 has been assigned to the Ministry of Natural Resources, and the interested parties in the period after written notice of objection or notice has been given, as well as handle the objection., so in the case of Article 55 states, criminal prosecution will be allowed if the provisions of Article 56 in respect of recognition of national resources 
has been implemented. "(Hodjati Palmer, 1385, p. 9) (6)

Fourthly) narrow interpretation of criminal law in favor of the defendant, where appropriate, the prosecution charged the national diagnostic certainty before being stopped.

Fifth) the theory No. 2047 / 17.03.1382 7. Legal Department of the Judiciary: "The prosecution of accused in determining punishment according to Article 690 of the Penal Code, if that is allowed by criminal complaint with the different parties in the property seized, not met. " since the public domain only if the full implementation of the provisions of Article 56 and the certainty of diagnosis, is established, and before the full implementation of the above provisions, the government seized property is not set, the prosecution of the proprietor to stop the certainty of diagnosis.

Single female staff to obtain ownership of the protesters attempt to call the office and authority of the Real Estate Registration has announced "The location and the location of the sub-plate does not match the ownership documents have been issued, separation of ownership documents issued to persons issued several times actual size. "According to the minutes of the Board of Inquiry No. 77 dated 09.11 .70 on the basis of a single article has announced, "As long as the relevant registration office, has not been issued a certificate of ownership, in an effort to address complaints from the staff of a single article is not allowed. "

Despite the wording of the law to stop the prosecution of the accused to fully implement the provisions of Article 56 and the verdict precedents No. 35-29 / 3/1353 General Assembly of the Supreme Court, and legal principles mentioned above, unfortunately there is no precedent in this area unit, and some national courts ruling condemning land occupied by non-deterministic, are exported, including the votes petition No. 198-17 / 7/1386 issued by Branch 1059 of Tehran's Criminal Court (especially the rights of public funds in the National Land and Natural Resources, Tehran) is, approved by Branch 42 of Tehran's Appeals Court is located, national detected, land disputes subject to final approval of the application of article 56, and the ability to recognize the object again, interested parties, including the owners attempted to protest plaque above the staff are single article.

Department of Natural Resources in 1383 in Tehran submitted a complaint to the court duress Boomehen, meet the national land tenure acting plates 79 and 78 are called the Tehran.

Branch Assistant Prosecutor General and Revolutionary Courts Boomehen with inquiries from the Department of Real Estate Registration Gholhak, ownership and registration plate above the Iranian government to put into question and the lack of registered office plaque above the corresponding branch of the government reports, because of the lack of ownership of the land occupied by that branch of the plaintiff injunctive indicted, No. 250 dated 29.2.84 and above the sentence issued by Branch 1086 of Tehran public court confirmed.

New Town Development Company subsequently campus, a separate complaint seeking prosecution brought acting plaque above, And the first branch Boomehen investigation due to a lack of ownership of the land occupied by the plaintiff dated 15.06.84 issued cease prosecution, No. 1008 dated 30.7.84 and above to the sentence issued by Branch 1086 of Tehran public court finds certainty.

Again in 1385, the District Court in Tehran 3 (especially the rights of the treasury) from the Department of Natural Resources former perfect application for re-charged and prosecuted to recommend the removal of paragraph 3 of Article 3 of the law courts and the public (due to new discoveries) will be raised defendants further pursue the issue.

District Court Branch 53 Tehran the culpability of the defendants issued a special litigation guardian to protect the rights of the public treasury the National Land and Natural Resources in the indictment punish the perpetrators, according to the article 690 of the Penal Code shall apply.

1059 Court of Criminal Tehran branch diagnosis dated 21/09/52 and 16/05/52 and banners on the leaves arguing that "a vote in favor of the General Board of the Supreme Court precedents No. 681 dated 07.26.84 that : "Construction Jihad Ministry of National Resources and exceptions specified in Article 2 of the Law of forests and pastures in accordance with Article 2 of the law of conservation and protection of natural resources and forest reserves in the country national resources belong to the Government of the Islamic Republic of Crimea had enough lack of ownership document issued by the government and the government does not rule out the property. " and to meet the government's ownership Rqbat possessions and ill defendants and destructive interactions in society and loss of owner Muslim public treasury they adapt to Article 690 of the Penal Code to one year in prison and iodine abstraction and extermination of buildings in the national arena and restore the former situation condemns.

Lawyers arguing that: First) provisions of Article 56 (b) rule of law and protection of the interest portion of forest and meadows and its subsequent amendments in respect of the implementation of the national proceedings are not primarily objection to a single article of the Board of plaques captured or for proving not commented national recognition of the uncertainty and lack of proof so.

B) Adopt an amendment of Article 55 of the law to protect the exploitation of forest and grasslands, as well as ratings precedents No. 35-29 / 3/1352 General Board of the Supreme Court the prosecution and punishment has been 
suspended on full implementation of the provisions of the National Land acting Article 56 is.

C) Narrow interpretation of criminal law in favor of the defendant, requires the adjudicating and national recognition of the uncertainty, the prosecution proprietor, is suspended.

Fourthly) ratings precedents No. 681 dated 07.26.84 General Board of the Supreme Court also emphasized the need for full implementation of the provisions of Article 56stressed and non-issuance of title deeds in the name of the state in state ownership does not rule out the assumption that the provisions of Article 56 of the is fully applicable to the appeal court to appeal their sentence.

Subsequently appealed the verdict, branch 42 of the Tehran Appeals Court adapt petition No. 128 dated 15.02.87 petition confirm primitive and simply because the abstraction of iodine and extermination of the building and the building in accordance with Clause 2 of Article 690 of the Penal Code, subject The petition is presented in this section violates Petition primitive act.

\section{Conclusion}

As was observed with the possibility of criminal prosecution acting national territory before the full implementation of the provisions of Article 56 Law on the Protection and Utilization of Forest and Rangeland two different approaches have been proposed.

First view emphasized the necessity of observing the rights and interest of the community, in line with the national law of the jungle material and material 2. Protection Act and the exploitation of forests and rangelands, complaining of forests and pastures and chase a watershed against acting Criminal acting prescribe them.

The second view, contrary to the first view, to preserve the rights of the accused and the prosecution and punishment ban him to fully implement the provisions of Article 56Law on the protection and exploitation of forests and rangelands, are considered. According to this view, according to an article Article 55 Law on the Protection and exploitation of forests and grasslands and ratings precedent No. 35 dated 03.29.1352 The General Assembly of the Supreme Court and the Theory No. 97698 / 7-23 / 12/78 Legal Department of the judiciary and the narrow interpretation of the criminal law in favor of the accused and also the ratings precedents No. 681 dated 26.07.84 Supreme Court, the proceedings before the definite diagnosis of natural resources does not exceed the legal justification and must be stopped.

It is the view of the principles of legal certainty and the rules, regulations, compliance and hope more aphids Da courts to follow precedent decision No. 35 dated 03.29.52 General Board of the Supreme Court and implementation of legal texts, precedent decision of National Land and acting prosecution to the full implementation of the provisions of Article 56 Law on the protection and exploitation of forests and rangelands, are suspended.

\section{References}

Assyrian, M., (2000), Code of Criminal Procedure, Volume I, sixth edition, Tehran.

Shams, Ahmad. (2005), the National Land Law, Second Edition, Tehran: Ministry of Justice.

Shams, B of Allah, (2006) Civil Procedure Code, Volume I, Fifth Edition, Tehran: amount.

Golduzian, I., (2007), Stuffed Penal Code, Second Edition, Tehran: the Parliament.

Hodjati ashrafi, Golamreza, (2006), Stuffed lands, Tehran: Publication treasure knowledge.

\section{Footnotes}

1 - Forest, Rangeland and Watershed country is now in charge of Iran's obligations under the Ministry of Agriculture Forest Service Contract.

2 - Public property or property that is used for direct all people dedicated to protecting the public interest and for the provincial government to which the public can handle it.

3- Accordance with the national law of the forest (Article 2 note 3) "areas and areas of arable land and gardens, as well as utilities and rural homes in the area, according to the law, only the ownership of forests and pastures that have been made to the date of enactment of this Act shall not be subject to the law 1 Ayn was "...

4- Possession, dominion and authority is customary human rights in its financial position, this authority is based on the effects of outside, however, be such that the norm as the proprietor of the copyright owner and the owner knows the financial predominate.

5 - Article 22 Registration Act "legal due process of law or by the expiration of the protest and appeal and litigious means that the ruling issued by the closed cases».

6- Qazvin justice majority, with the possibility to punish offenders national territory, so the lack of implementation of the provisions of Article 56, said, as foresters uncertain terms at any time of the commission of land disputes in the implementation of Article 56 of the final single article, investigation is objectionable; this objection is no statutory deadline, with regard to decision No. $35-29 / 3 / 1353$ precedents, the Commission voted to issue a single article mentioned before, accused of raping such lands, cannot prosecute. These terms have been approved by the Commission on Judicial Education. Quote from: meetings of Justice, the Penal Code, Vol. 2, p. 1461. 